\title{
Effect of Epigallocatechin-3-Gallate (EGCG) on the number of lymphocyte cells in inflammation of pulp with mechanical injury
}

\author{
Kun Ismiyatin, Latief Mooduto and Putri Dea Amani Faadhilah \\ Department of Conservative Dentistry, \\ Faculty of Dental Medicine, Universitas Airlangga, \\ Surabaya, Indonesia
}

\begin{abstract}
Background: Pulpitis is an inflammatory pulp that can caused by pulp perforation by mechanical injury. Emergency treatment of pulpitis is using Eugenol. High concentrations of Eugenol have a cytotoxic effect that causes local necrosis and inhibits the healing process. Because of negative effects from eugenol, then it's necessary to consider a new ingredient with minimal side effects, and it's epigallocatechin-3-gallate (EGCG) in green tea. As a polyphenol, it has good antioxidant effect and plays a role in shortening the duration of inflammation by radical scavenging against Nitric Oxide so that NO levels rapidly decrease which causes migration of neutrophil cells to the area of injury will decrease and the inflammatory process faster so that the healing process become faster. Lymphocyte is plays a role in tissue repair. Purpose: to explain the effect of EGCG hydrogel on the number of lymphocyte cells in pulp inflammation with mechanical injury. Methods: The study used 24 Wistar rats divided into four groups, namely control (C), and 3 groups of treatment (T1, T2, T3). Each group consisted of 6 rats prepared, then EGCG hydrogel 60 ppm was named T1, EGCG hydrogel 90 ppm was named T2, EGCG hydrogel 120 ppm was named P3. On the 3rd day, Wistar rats were decapitated for HPA preparations. Results: This study showed a significant difference in each group $(p<0.05)$ using One-Way Anova analysis. Conclusion: EGCG hydrogel 90 ppm is effective in increasing the number of lymphocyte cells in inflammation of the pulp with mechanical injury.
\end{abstract}

Keywords: Epigallocatechin-3-gallate; hydrogels; lymphocytes; inflammation of the pulp

Correspondence : Kun Ismiyatin, Department of Conservative Dentistry, Faculty of Dental Medicine, Universitas Airlangga, Jl. Mayjen. Prof. Dr Moestopo No.47, Surabaya, Indonesia, 60132. E-mail: kun-is@fkg.uanir.ac.id

\section{INTRODUCTION}

Based on Al-Hisayat's research (2006) showed that the prevalence of perforation in dental pulp as much as $44.1 \%$ of 204 pulpitis teeth caused by mechanical injury. ${ }^{1}$ Pulpitis is an inflammation in dental pulp tissue with pain symptoms. Clinically classified of pulpitis is reversible and irreversible. ${ }^{2}$ Histopathologically, pulpitis is classified into acute and chronic. Acute pulpitis has sharp pain symptoms that appear suddenly and occur due to injury from deep preparation or caries. ${ }^{3,4}$ Chronic pulpitis is a pulpitis that has occurred for a very long time and has dull pain symptoms. ${ }^{5}$

Pulpitis is similar to inflammation of the connective tissue so that the cells have role are polymorphonuclear leukocytes and mononuclear leukocytes include macrophages and lymphocytes. Lymphocytes are a type of white blood cell and include chronic inflammatory cells found in chronic pulpitis. ${ }^{6,5}$ Lymphocytes migrate to the lesion area on the 3rd day after injury until the 7 th day. ${ }^{7,8}$ Lymphocytes play a role in the process of bacterial phagocytosis and play a role in stimulating fibroblasts for the formation of new tissue by secreting FGF with macrophages. Lymphocytes have a life span of weeks or months depending on the body's need for these cells..$^{9,10}$

In the dentistry, treatment performed to reduce pain in pulpitis is using eugenol. ${ }^{6}$ Eugenol has the disadvantages of being a weak antioxidant because it has only one phenol group (-OH) and its use with high concentrations (74.3\%) for the treatment of pulpitis currently causes local necrosis because it's cytotoxic, and inhibiting the wound healing process. ${ }^{11,12}$ Eugenol also has a spicy flavor. ${ }^{13}$ The smell of eugenol is also so strong that it causes the patient to become afraid and anxious when going for treatment. ${ }^{14}$

Herbal plants are widely used in the development of natural medicine technology as an alternative medicine, one of which is green tea. Epigallocatechin-3-gallate (EGCG) is a polyphenol that is included in the active compound of flavonoids from green tea has antioxidant, anti-inflammatory, antibacterial properties and acts as an immunomodulator. EGCG is antioxidant because the 
polyphenol structure of EGCG can reduce levels of nitrite oxide (NO) with the process of radical scavenging so that it causes a decrease in neutrophil cell migration to the lesion area and causes the proliferation phase to occur earlier so that the wound healing process takes place faster. EGCG has also been shown to stimulate the production of IL-1 $\alpha$, IL$1 \beta$, monocytes and lymphocytes. ${ }^{8,15,16,10}$ Based on research Ismiyatin et al (2018) showed that EGCG hydrogel 75 ppm is more optimal than $25 \mathrm{ppm}$ in pulpal inflammation. EGCG hydrogels $60 \mathrm{ppm}$ and $120 \mathrm{ppm}$ have better biocompability than EGCG solutions because they have a $60 \%$ higher percentage of living cells compared to solutions reaching $50 \%$ in in vitro biocompability studies in EGCG hydrogels in fibroblast culture. ${ }^{17}$

The study was conducted to explain the effect of EGCG as one of the polyphenol flavonoid compounds and determine the effectiveness of EGCG hydrogel 60 ppm, 90 ppm, 120 ppm on the number of lymphocyte cells that play a role in the healing process of pulpitis due to mechanical injury on day 3 in Wistar rats models.

\section{MATERIALS AND METHODS}

This research is an experimental laboratory research with randomized post test only control group design. The sample used in this study was 24 male Wistar rats (Rattus novergicus) with body weight 200-300 grams, age 3 months. The material used in this study is EGCG which is the result of extraction from green tea, EGCG dissolved with polyethylene glycol (PEG) hydrogel base with 60 ppm, $90 \mathrm{ppm}$, and $120 \mathrm{ppm}$ concentrations. EGCG hydrogel was applied topically to cavity. The experimental animals were randomly divided into 4 groups, 1 control group of 6 rats each and 3 treatment groups of 6 rats each. This study was approved by the Ethics Commission of the Faculty of Dentistry, Airlangga University (Number: 488 / HRECC. FODM / VII / 2019).

Before cavity preparation, rats were anesthetized intramuscularly with $0.2 \mathrm{ml}$ of a mixture of $0.5 \mathrm{ml}$ of ketamine (PT Kepro B.V., Deventer, Holland) and 0.5 Xyla $^{\circledR}$ xylazine (PT Tekad Mandiri, Bandung, Indonesia). Preparation was performed on the occlusal surface of upper right first first molar maxillary using a Edenta ${ }^{\circledR}$

Table 1. Mean of Lymphocyte Cell Proliferation

\begin{tabular}{llcc}
\hline Group & $\mathrm{n}$ & Mean & $\mathrm{SD}$ \\
\hline $\mathrm{C}$ & 6 & 4.8333 & 0.75277 \\
$\mathrm{~T} 1$ & 6 & 7.0000 & 0.89443 \\
$\mathrm{~T} 2$ & 6 & 10.6667 & 1.21106 \\
$\mathrm{~T} 3$ & 6 & 11.5000 & 1.04881
\end{tabular}

Notes: $\mathrm{n}=$ Total sample; $\mathrm{C}=$ Given injury without treatment; $\mathrm{T} 1=$ Treated by EGCG hydrogel $60 \mathrm{ppm} ; \mathrm{T} 2=$ Treated by EGCG hydrogel $90 \mathrm{ppm}$; T3 = Treated by EGCG hydrogel $120 \mathrm{ppm}$. diamond round bur with $0.8 \mathrm{~mm}$ in diameter (Edenta corp, Switzerland) with depth to reach the pulp base (about $1.5 \mathrm{~mm}$ ), followed by a sonde until the perforation was marked by bleeding and checking with Inline ${ }^{\circledR}$ paper points (B.M. Dentale S.a.s, Torno, Italy). EGCG hydrogel was measured using a Acura ${ }^{\circledR}$ micropipette (Acura manual 825, Socorex Isba Sa, Switzerland) then applied to the cavity using a TPC ${ }^{\circledR}$ microbrush (TPC Advances Tech.Inc, USA). EGCG hydrogel concentrations 60 ppm (T1), EGCG hydrogel concentrations 90 ppm (T2), and EGCG hydrogel concentrations 120 ppm (T3) were applied on the cavity. Furthermore, the cavity was overtaken with a temporary lift Glass Cement Gold Label ${ }^{\circledR}$ (GC Corp, Tokyo, Japan). ${ }^{18}$

On the 3rd day, the animals were decapitated and the jaw of molar teeth were taken then fixed with $10 \%$ buffered formalin Polysciences ${ }^{\circledR}$ (Polysciences Inc, US) and decalcified using 10\% EDTA pH 7.4 RPI $^{\circledR}$ (RPI Corp, USA). Then preparations are made for histopathological examination under a microscope with Hematoxcylin-Eosin (HE) stain. The preparations are viewed under a microscope with 400x magnification and then counted lymphocyte cells by double blind test technique by two pathologists.

Data on the number of lymphocyte cell from each group were tested for normality using the Kolmogorov Smirnov test (one-sample K-S). Data is normally distributed if the $p$ value (asymp sig) $>0.05$. The data is normally distributed were tested by Independent T-Test to determine the significance of the differences between the control and treatment groups with a significance value $(p<0.05)$. Then the results of the treatment group research data were carried out homogeneity tests using the Levene's Test followed by the One-way ANOVA test to find out the distribution of the data. The data is normally distributed were forwarded with Turkey HSD to determine differences between treatment groups, significantly differences were marked by sig values smaller than $0.005(\mathrm{p}<0.005)$.

\section{RESULTS}

Lymphocytes with HE staining appear round with a small size and have a curved nucleus with a slightly granular cytoplasm. ${ }^{6}$ The results of calculation of the average number of lymphocyte cell can be seen in the Table 1 .

Table 2. Result of Statistic Post Hoc Test Tukey HSD from Lymphocyte Proliferation

\begin{tabular}{|c|c|c|c|c|}
\hline & $\mathrm{C}$ & $\mathrm{T} 1$ & $\mathrm{~T} 2$ & T3 \\
\hline $\mathrm{C}$ & & $0.006^{*}$ & $0.000^{*}$ & $0.000^{*}$ \\
\hline $\mathrm{T} 1$ & & & $0.000^{*}$ & $0.000^{*}$ \\
\hline $\mathrm{T} 2$ & & & & 0.481 \\
\hline T3 & & & & \\
\hline
\end{tabular}


Based on Table 1, the treatment group by giving EGCG hydrogels $60 \mathrm{ppm}, 90 \mathrm{ppm}$, and $120 \mathrm{ppm}$ can increase the number of lymphocyte cells. To clarify the number of lymphocytes in each group can be seen in Figure 1.

Based on the data at Figure 1, it can be seen that the higher the concentration of EGCG, the higher the average number of lymphocyte cells present in the pulp tissue on the $3^{\text {rd }}$ day after treatment. After the data is obtained, data analysis is performed.

Table 2 showed statistically significant differences between the control group with treatment group 1, the control group with treatment group 2 , the control group with treatment group 3, treatment group 1 with treatment group 2, and treatment group 1 with treatment group 3 .

\section{DISCUSSION}

This research is an experimental laboratory study and have purpose to analyze the concentration of EGCG hydrogels that are effective in increase the number of lymphocyte cells from dental pulp tissue in inflammation of the dental pulp of wistar rats. This research was carried out on the maxillary first molars of wistar rats by preparation using a high speed handpiece with a diamond bur of $0.8 \mathrm{~mm}$ in diameter and the cavity was irrigated with sterile saline solution after dried with a cotton pellet. Preparation is carried out until the dentinal tubules open with minimal damage to reach the pulp roof and then evaluate the bleeding using a paper point. The presence of blood indicates that the preparation

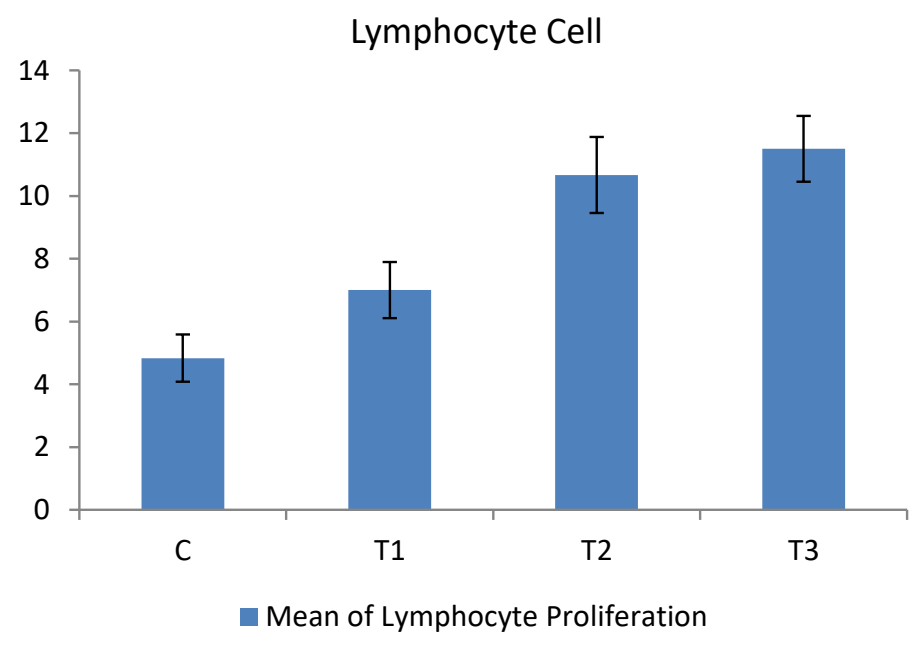

Figure 1. Graph of Lymphocyte Proliferation Mean. $C=$ Control (injury without treatment), $T 1=$ Treatment group 1 (Treated by EGCG hydrogel 60 ppm), T2= Treatment group 2 (Treated by EGCG hydrogel 90 ppm), T3= Treatment group 3 (Treated by EGCG hydrogel 120 ppm).
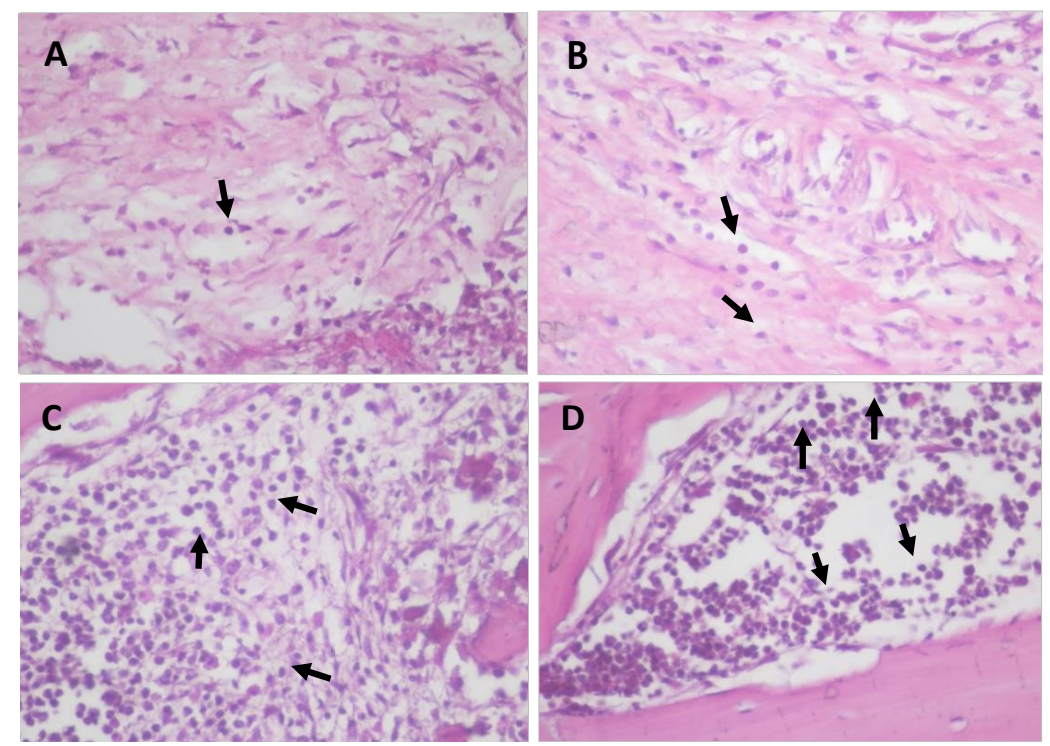

Figure 2. Photograph result of HPA examination of lymphocyte cells on day $3 ; \mathrm{A}=\mathrm{Control}$ (injury without treatment), $\mathrm{B}=\mathrm{T} 1$ (Treated by EGCG hydrogel 60 ppm), C= T2 (Treated by EGCG hydrogel 90 ppm), D= T3 (Treated by EGCG hydrogel 120 ppm). At the tip of the arrow are lymphocyte cell with 400x magnification. 
has reached the roof of the pulp. ${ }^{19}$ Preparations were made to obtain perforations due to mechanical injury and then topical extract of EGCG was applied and a layering was carried out to avoid contamination of food. Consideration of selection of experimental animals of male Wistar rats (Rattus norvegicus) because the biological reaction of the healing process of pulp tissue is similar to human teeth and minimizes hormonal influences during treatment which can affect the results of research. ${ }^{20}$

Herbal plants are widely used in the development of natural medicine technology as an alternative medicine, one of which is green tea. EGCG has a role as an antioxidant, anticarcinogenic, anti-inflammatory. ${ }^{19}$ EGCG is also included in flavonoids because it's a phenol derivative that is synthesized in a certain amount but widely distributed and has a role in wound healing. ${ }^{21}$ EGCG is rich in phenolic hydroxyl groups $(\mathrm{OH})$ so it has many beneficial health activities. $^{22}$

The purpose of the application of EGCG hydrogel is as an alternative to the use of euganol in pulpitis emergencies treatment with the function of overcoming inflammation and pain caused by mechanical injury and hydrogel form is chosen because of its ability to regulate extract release and protect extract content from the external environment. ${ }^{19}$ and have good spreadability. ${ }^{23}$ In this study use $98 \%$ pure EGCG extract in the form of white powder used as hydrogel with concentrations of $60 \mathrm{ppm}, 90 \mathrm{ppm}, 120 \mathrm{ppm}$.

High antioxidants in EGCG cause the wound healing process to be faster because the polyphenol structure of EGCG can reduce levels of NO with the process of radical scavenging, and it caused a decrease in neutrophil cell migration to the lesion area and cause the proliferation phase to occur earlier. ${ }^{8,15,16}$ Lymphocytes is a chronic inflammatory cells and have a role in the process of bacterial phagocytosis and play a role in stimulating fibroblasts for the formation of new tissue in the wound healing process by secreting FGF with macrophages. Lymphocytes migrate to the lesion area on the third day after injury until the seventh day. ${ }^{6,5,9,10}$

In this study, 24 Wistar rats were used which were then divided into 4 treatment groups (C, T1, T2, and T3) with 6 in each group. Group $\mathrm{C}$ is a group of mice that after preparation were not given extracts of EGCG hydrogel in the cavity and were given a lift. Group T1, T2, and T3 are groups of mice after preparation EGCG hydrogel was applied to the cavity with concentrations 60 ppm, 90 ppm and 120 ppm and then given a temporary restriction with GIC type 2. Each group, carried out the decapitation of rats on day to day-3 and then preparations are made for histopathological examination to calculation of the number of lymphocyte cells after treatment.

Based on the results on day 3 showed a difference in the control group (C) with treatment (T1) given $60 \mathrm{ppm}$ EGCG hydrogels. The data shows the average number of lymphocytes in $\mathrm{T} 1$ is higher than the control with the number of $\mathrm{T} 1=7$ and $\mathrm{C}=4.83$. The results in groups $\mathrm{T} 2$ (EGCG 90 ppm) and T3 (EGCG 120 ppm) showed that the average number was higher compared to the control group and $\mathrm{T} 1$ with the average number $\mathrm{T} 2=10.67$ and $\mathrm{T} 3=11.5$.
This proves that the application of EGCG hydrogels can increase the number of lymphocyte cells.

The increased of lymphocytes can be observed on the 3rd day after treatment because lymphocytes migrate to the lesion area on day 3 to day 7 after injury. Significant increase in the number of lymphocytes may be due to the application of EGCG hydrogel containing flavonoid active compounds in the form of polyphenols so that they are antioxidant. ${ }^{7,8,24}$ The results of this study are consistent with the research of Rahayu et al (2018) EGCG proven to be able to stimulate the production of IL- $1 \alpha$, IL- $1 \beta$, monocytes and lymphocytes due to the polyphenol EGCG structure and antioxidant properties so as to reduce NO levels through radical scavenging processes then cause a decrease in neutrophil cell migration to the lesion area and then neutrophils are soon replaced by macrophages and lymphocytes so that the wound healing process takes place more faster. ${ }^{8,15,16}$

According to statistical test results, there were significant differences between the $\mathrm{C}$ (control) group and the T1 (EGCG 60 ppm) group, T2 (90 ppm EGCG) and T3 (120 ppm EGCG) group. There was a significant difference between group T1 (EGCG 60 ppm) with group T2 (EGCG $90 \mathrm{ppm}$ ) and group T1 (EGCG $60 \mathrm{ppm})$ and group T3 (EGCG 120 ppm). Meanwhile, there was no significant difference between group T2 (EGCG 90 ppm) and group T3 (EGCG 120 ppm).

Significant differences in the number of lymphocytes between the control and treatment groups indicate the effect of the application of EGCG hydrogels. Significant differences between groups $\mathrm{C}$ (control) with groups $\mathrm{T} 1$ (EGCG 60 ppm), T2 (EGCG 90 ppm) and T3 (EGCG 120 $\mathrm{ppm}$ ) indicate that there is an acceleration of activation and infiltration of lymphocytes in tissues affected by injury in the treatment group given EGCG hydrogel. With an increased number of lymphocytes and accelerated lymphocyte infiltration, it shows that the process of radical scavenging occurs faster so that neutrophils are soon replaced by macrophages and the inflammatory process becomes faster so that healing and repair of tissue occurs faster. ${ }^{8,15,16}$

Significant differences between the control group and T1 (EGCG with $60 \mathrm{ppm}$ ) indicate that EGCG with a concentration of $60 \mathrm{ppm}$ has a significant effect in increasing the number of lymphocyte cells. The insignificant difference in T2 and T3 groups is shown by the number of lymphocytes in the two groups having not large differences in numbers. It appears that the group given EGCG hydrogel with a concentration of $90 \mathrm{ppm}$ is effective in increasing the number of lymphocytes to nearly equal the number of lymphocytes in the group given EGCG hydrogels with a concentration of $120 \mathrm{ppm}$. This shows that EGCG hydrogel with a concentration of $90 \mathrm{ppm}$ has been able to increase the number of lymphocytes but at a concentration of $120 \mathrm{ppm}$ more effective in increasing the number of lymphocyte cells is shown with higher results compared to the 90 ppm EGCG group. This insignificant difference between the number of lymphocyte cells at concentrations of $90 \mathrm{ppm}$ and 120 ppm indicates that the application of high concentrations of EGCG will have an inadequate effect because the 
application of EGCG with a higher concentration will make the tissue state saturated. ${ }^{25}$

This study proves that the extract of EGCG hydrogel has the benefit of increasing the number of lymphocyte cells on the 3rd day of inflammation of the pulp with mechanical injury by shortening inflammation and accelerating the proliferative phase so that tissue repair occurs faster so that inflammation is not sustainable which can lead to pulp necrosis.

The research conducted at this time still has many shortcomings and limitations among others, research conducted on the follow-up of male Wistar (Rattus Norvegicus) with a limited amount. The dynamics of research ratios only apply between groups with different concentrations over a period of 3 days and do not explain the ratios between different time periods. In carrying out this study there are limitations to using only biomarkers at the cellular level, so the results of this study are unable to explain the facts about the molecular mechanisms involved in pulp inflammation with mechanical injury in Wistar rats.

\section{CONCLUSION}

The conclusion of this study is EGCG hydrogel with a concentration of $90 \mathrm{ppm}$ effective and has a significant influence in increasing the number of lymphocyte cells in inflammation of the pulp with mechanical injury.

\section{REFERENCES}

1. Al-Hisayat, A.S., Barrieshi-Nusair, K.M., Al-Omari, M. A. The radiographic outcomes of direct pulp-capping procedures performed by dental students. A Retrospective study. JADA. 2006; 137:1699-1705

2. Piattelli, A. and Traini, T. Diagnosis And Managing Pulpitis Reversible or Irreversible?. PPAD. 2007; 19(2): A.

3. Abbot, P. and Yu, C. A clinical classification of the status of the pulp and the root canal system. Australian Dental Journal Supplement, 2007; 52(1): S20.

4. Kabir, R., Jahan, N., Sultana, N. and Choudhury, R. Antinociceptive and Anti-inflammatory Effects of Diclofenac Sodium Along with B Vitamins on Acute Pulpitis. J Bangladesh Soc Physiol, 2016; 11(1): 29.

5. Giuroiu, C. L., Caruntu, I. D., Lozneanu, L., Melian, A., Vataman, M., Andrian, S. Dental Pulp: Correspondemces and Contradictions between clinical and histological diagnosis. Biomed Research Int. 2015; 15: 2.

6. Enggardipta, R., Haniastuti, T. and Handajani, J. Efek eugenol terhadap jumlah sel inflamasi pada pulpa gigi molar tikus Sprague Dawley. Majalah Kedokteran Gigi Indonesia. 2016; 2(2): 68, 70-71.

7. Velnar, T., Bailey, T., Smrkolj V. The Wound Healing Process: an Overview of the Cellular and Molecular Mechanism. International Medical Research. 2009; 37(5): 1533.

8. Broughton, G., Janis, J., and Ttinger, C. The Basic Science of Wound Healing, Plastic and Reconstructive Surgery, 117 (SUPPLEMENT). 2006: 125-325.

9. Guyton C, Hall J. E. Terjemahan Buku Ajar Fisiologi Kedokteran. Edisi 12. Singapore: Elsevhier. 2016.
10. Townsend, M. C., Beauchamp, R. D., Evers, B. M. and Mattox, L. K., 'Qound Healing' in Sabiton's Textbook of Surgery: The Biological Basis of Modern Surgical Practice. $20^{\text {th }}$ ed., Philadelphia: Elsavier Inc. 2017.

11. Deshpande, A., Verma, S., dan Macwan, C. 'Allergic Reaction Associated with the use of Eugenol Containing Dental Cement in a Young Child', Austin Journal of Dentistry. 2014; 1(2): 1-3

12. Bendre, R. S. et al. 'Outlooks on Mendicinal Properties of Eugenol and its Synthetic Deivatives', Natural Products Chemistry \& Research. 2016; 4(3): 1-6.

13. Tohawa, J. MANFAAT EUGENOL CENGKEH DALAM BERBAGAI INDUSTRI DI INDONESIA The Benefits of Cloves Eugenol in Various Industries in Indonesia. Perspektif. (2012); 11(2): 79-80.

14. Toet, A. et al. 'Effects of Pleasant Ambient Fragrances on Dental Fear : Comparing Apples and Oranges', Journal of Chemosensory Perception. 2010; 3: 182-189. doi: 10.1007/ s12078-010-9078-9.

15. Mahmood, T., Akhtar, N. and Khan, B. The morphology, characteristic, and medicinal properties of Camellia Sinensis' tea. Journal of Medicinal Plants Reasearch. 2010; 4(19): 2030-2031.

16. Rahayu, R. P., Prasetyo, R. A., Purwanto, D. A., Kresnoadi, U., Iskandar, R. P. D., Rubianto, M. The immunomodulatory effect of green tea (Camellia Sinensi) leaves extract on immunocompromised Wistor rats infected by Candida albicans, Veterinary World. 2018; 11(6): 766.

17. Delicia, D. Biokompatibilitas Epigallocatechin Gallate Dalam Gel Polyethylene Glycol Terhadap Sel Limfosit Gingiva Manusia. Airlangga University; 2017;43

18. Nirwana, I. Aktivitas Ekstrak Buah Delima (Punica granatum linn) sebagai matrial pulp capping terhadap ekspresi IL-6, IL10, TGF $\beta-1$ dan kolagen tipe 1 pada gigi perforasi mekanik. Surabaya: Universitas Airlangga; 2012.

19. Ismiyatin, K. et al. 'Effect of Topical Epigallocatechin-3gallate on Lipopolysaccharide-induced Pulpal Inflamation in Rat Models', Iranian Endodontic Journal. 2018; 13(4): 528533.

20. Dammasche T, Stratman U, Fisher RJ, Sagher E. Proliferation of rat molar pulp cells after direct pulp capping with dentine adhesive and calcium hydroxide, Clinical Oral Investigations. 2014; (5):559.

21. Kurnia, P. and Ardhiyanto, H. Potensi Ekstrak Teh Hijau (Camellia Sinesis) Terhadap Peningkatan Jumlah Sel Fibroblas Socket Paska Pencabutan Gigi pada Tikus Wistar. E-journal Pustaka Kesehatan. 2015; 3(1): 123.

22. Shi, M., Shi, Y., Li, X., Yang, R., Cai, Z., Li, Q., Ma, S., Ye, J., Lu, J., Liang, Y. and Zheng, X. Food-Grade Encapsulation Systems for (-)-Epigallocatechin Gallate. Molecules. 2018; 23(445): 1-3.

23. Setiawan, I., Lindawati, N. and Amalia, B. Formulasi dan Uji Antiinflamasi Sediaan Hidrogel Ekstrak Jahe Merah (Zingiber Officinale). Media Farmasi Indonesia. 2018; 13(1): 1332-1333.

24. Mereles, D. and Hunstein, W. Epigallocatechin-3-gallate (EGCG) for Clinical Trials: More Pitfalls than Promises?. International Journal of Molecular Sciences. 2011; 12: 55925593

25. Dewi, K., Khlong, K. The Effect of Epigallocathechin-3gallat (EGCG) and Epigallocathechin (EGC) in green tea on weight loss leucocyte proliferation and histological features of colon in DSS induced colitis swiss webster male mice. 6th APICA \& 13th PIN-PAAI. 2011; P.18. 